\title{
An assessment of pharmaceutical waste management in some Nigerian pharmaceutical industries
}

\author{
Ngwuluka, Ndidi C. ${ }^{1 *}$, Ochekpe, Nelson $A .{ }^{2}$ and Odumosu, Patricia O. $^{2}$ \\ ${ }^{1}$ Department of Pharmaceutics, Faculty of Pharmaceutical Sciences, University of Jos. P. M. B. 2084, Jos. Nigeria. \\ ${ }^{2}$ Department of Pharmaceutical Chemistry, Faculty of Pharmaceutical Sciences, University of Jos. P. M. B. 2084 , Jos. \\ Nigeria.
}

Accepted 28 April, 2011

\begin{abstract}
Thirty four (34) of the fifty (50) selected Nigerian based pharmaceutical businesses, mainly acting as local manufacturers and major importers of medicines were interviewed using questionnaires to ascertain their waste management practices, knowledge of waste management policies and subjection to regulatory control. This study indicated that like its counterpart industry in other countries of the world, the Nigerian pharmaceutical industry generated both hazardous and non-hazardous wastes. However, the wastes were not categorized, poorly managed by $91.2 \%$ of the respondents, while $58.8 \%$ of the health and safety personnel had little or no modern knowledge of waste management. Furthermore, $73.5 \%$ of the respondents claimed that they were aware of the regulatory requirements on waste, but no adherence was observed. The industry did not benefit from the strict supervisions of regulatory agencies. Pharmaceutical waste was improperly disposed and all the secondary manufacturers $(\mathbf{7 9 . 4 \% )}$ discharged wastewater without removal of pharmaceuticals. This study highlighted the urgent need to train personnel in the pharmaceutical industry and regulatory authorities. Management of waste should be planned, documented, implemented and sustained.
\end{abstract}

Key words: Pharmaceutical waste, pharmaceuticals, wastewater, waste management, environment, regulatory authorities, effluent.

\section{INTRODUCTION}

Four to five decades ago, the focus of developed countries was how to prevent industrial and domestic waste from entering the waterways. Treatment plants were employed to improve the quality of water before wastewater was discharged into the lakes and rivers. While industrial waste and domestic waste were being managed, pharmaceutical waste became the emerging contaminant as it was discovered that it was neither completely removed nor degraded in the treatment plants (Ternes, 1998; Buser et al., 1999; Stumpf et al., 1999; Latch et al., 2003).

Pharmaceuticals, though used to treat and manage diseases, are poisons which justifies the growing

\footnotetext{
Corresponding author. E-mail: Ndidi.Ngwuluka@biodrudel.com.
}

concerns about their presence in the environment. A typical example is paracetamol, which is a commonly used over-the-counter drug that can induce liver failure on high doses. If dose is a determinant of the toxicity of drugs, are the concerns about pharmaceuticals in the environment misplaced when it can be argued that the quantities in the environment may not be at toxic levels? Considering the fact that wastewater is being increasingly recycled for agricultural use and there is increased pharmaceutical use and disposal in highly populated countries, then the health and environmental concerns may be justified.

Pharmaceuticals have not only been found in wastewater, but also in surface, ground and drinking waters (Jones et al., 2002; Zuccato et al., 2006; Castensson, 2008; Heberer, 2002; Kümmerer, 2008; Keil et al., 2008). A review was written on the occurrence of pharmaceuticals in the sewage, ground, surface and drinking waters 
(Heberer, 2002). The studies undertaken in about ten countries detected more than 80 pharmaceuticals in sewage, ground and surface water to the level of $\mu \mathrm{g} / \mathrm{L}$ and traces in drinking water. One of the concerns is the possible impact of the accumulation of pharmaceuticals in humans and aquatic animals over a prolonged period as some of them are known to persist in the water environment (Hektoen et al., 1995; Selvik et al., 2002). Presently, the apparent major concern is the effect of pharmaceuticals on aquatic organisms (Sherer, 2006) as the extent of the impact on human is not as defined. Effects on aquatic organisms have been studied (Cleuvers, 2003; Fenske et al., 2005; Huggett et al., 2002; Lange et al., 2001; Henschel et al., 1997; Pomati et al., 2004; De Lange et al., 2006) and these include inhibition of growth, production of stress hormone (abscisic acid), feminization and behavioural changes. Furthermore, pharmaceutical mixtures (ibuprofen, fluoxethin and ciprofloxacin) have been shown to cause mortality of fish in $\mu \mathrm{g} / \mathrm{L}$ range (Richards et al., 2004). An indirect effect has also been observed in a study which attributed diclofenac residues to the population decline of vultures in Pakistan (Oaks et al., 2004).

Sources of pharmaceutical wastes include excreted substances, improper disposal by hospitals and patients, agricultural waste due to veterinary use and livestock feed additives (Zuccato et al., 2000; Heberer, 2002) and manufacturing industries. It is understood that in the United States, waste from the pharmaceutical industries are being monitored (Castensson, 2008). In fact, the leading international pharmaceutical industries over the years have made waste management part of the overall management system to improve their performance in the field of health, safety and environment. A review on the pharmaceutical industries and the progress they have made in environmental management by generating health, safety and environment programs, preventing pollution, waste minimization, recycling and reusing of materials, and investing in projects and facilities to ensure environmental sustainability have been published (Berry and Rondinelli, 2000). Their annual reports can be obtained from their websites indicating the progress they have made on waste management. Some of the Industries include Merck, Eli lily, Sanofi-Aventis, AstraZeneca, GlaxoSmithkline, Novartis and Roche.

In countries, such as United Kingdom, United States of America and Germany, the concentrations of pharmaceuticals in treated wastewater, surface water and ground water are in the range of $\mathrm{ng} / \mathrm{L}$ and in some cases $\mu \mathrm{g} / \mathrm{L}$ (Fent et al., 2006). However, the concentrations of pharmaceuticals in Asian countries, such as India, were much higher in the range of $\mathrm{mg} / \mathrm{L}$ (with ciprofloxacin having the highest concentration of 28 to $31 \mathrm{mg} / \mathrm{L}$ ) (Larsson et al., 2007; Li et al., 2008). The studies by Larsson et al. (2007) and Li et al. (2008) buttress the point that pharmaceutical industries, especially in deveping countries may be major sources of pharmaceutical waste in the water environment.

A report (unpublished) on the history of the pharmaceutical industry indicated that the advent of Nigerian pharmaceutical industry began with some multinational companies having sales outlets in the country purely to meet pharmaceutical needs. The early sixties saw the emergence of some tertiary manufacturers of pharmaceutical products. Tertiary manufacturers, then, were involved in the bulk importation of already formulated medicines to break the bulk and package locally. Later, indigenous secondary manufacturers began to emerge, but were initially limited to tableting and liquid mixing operations. However, the manufacturing industry has made some progress, though slowly. Currently, some companies have gone into other dosage forms such as creams, emulsions, liniments and sterile products. Nigeria is yet to have a primary manufacturer that produces bulk active ingredients. The existing companies that produce finished products today import most excipients, and all the active ingredients.

Among the other challenges that face the Nigerian pharmaceutical industry, is the issue of pharmaceutical waste and its impact on the environment and public health. No matter the type/level of production or pharmaceutical business, the pharmaceutical industry generates pharmaceutical waste. While countries such as Italy (Zuccato et al., 2005; Zuccato et al., 2006), Germany (Ternes, 1998; Sacher et al., 2001), United States (Erickson, 2002), United Kingdom (Bound and Voulvoulis, 2006; Roberts and Thomas, 2006), Taiwan (Lin and Tsai, 2009), India (Fick et al., 2009) have been determining and monitoring pharmaceutical waste, there is no apparent indication that Nigeria is monitoring it and there is little or no awareness that pharmaceutical waste is an emerging contaminant with growing concern. If hundreds of tons of pharmaceutical substances enter the sewage treatment plant given to about 60 million people each year in Italy, it raises concern for Nigeria with a population of 150 million people. Some studies have been undertaken in Nigeria to assess the management of healthcare waste (Bassey et al., 2006; Coker et al., 2009; Longe and Williams, 2006; Ngwuluka, et al., 2009) and in sum, it can be adjudged that healthcare wastes are poorly managed in Nigerian hospitals. Although, some of the Nigerian pharmaceutical industries were started by some international counterparts, we hypothesized that the local industries fall short in management of pharmaceutical waste.

Therefore, this study was undertaken to obtain data on pharmaceutical waste and its management from the pharmaceutical industries in Nigeria - the types and quantities of waste generated and disposed by these industries, in order to assess their waste management practices in comparison with international standards and recommendations, and to assess the awareness of the industries on the regulatory requirements and the impact of waste regulation on the industries. 


\section{MATERIALS AD METHODS}

The data-collection method employed in this study was the use of questionnaire administered through interview. The questions were written to meet the objectives. The fact that it was an interview enabled further clarifications of the questions if required by the respondents to assist them answer the questions appropriately. The key people interviewed varied from industry to industry based on who the industries thought were suitable to answer the questions. These people included quality control/assurance managers, regulatory officers, superintendent pharmacists and environmental officers. Fifty (50) industries were visited and each interview lasted between half an hour to one hour. The visits and interviews were personally undertaken by the authors.

\section{Structure of questionnaire}

The questionnaire had 10 major questions with some subquestions. The questions included contact details, type of business, installation and production capacity, list of products manufactured or imported, type of waste generated and quantity, waste management practices, personnel and training, regulatory requirements and management of product recall.

\section{Pre-testing of questionnaire}

The questionnaire was tested in two pharmaceutical industries in Jos, Plateau state, which enabled further improvement of the questionnaire before the actual survey.

\section{Survey locations}

Pharmaceutical Industries in four Nigerian states - Lagos, Ogun, Niger and Plateau states - were visited. Lagos and Ogun states, located in the South-west of Nigeria, accounted for $88 \%$ of the industries while Niger and Plateau states located in the middle-belt region of the country accounted for 4 industries visited. The industries used during pre-testing were excluded in the actual survey.

\section{Analysis of data}

The data obtained following the administration of the questionnaire were presented in simple percentages of the numbers that responded to each interview question.

\section{RESULTS AND DISCUSSION}

\section{Profiling of the pharmaceutical industries}

There are over 100 pharmaceutical manufacturing industries and major importers of medicines in Nigeria; though, not all are registered members of pharmaceutical manufacturers group of manufacturers association of Nigeria (PMG-MAN). It is also estimated that more than $50 \%$ of them are situated in Lagos. This could be due to the proximity of the sea port as a number of drugs and most of the raw materials are imported. Furthermore, it is attributed to the fact that Lagos still remains the commercial capital of Nigeria. Fifty (50) pharmaceutical industries were visited, and 34 responded to the interview conducted with the questionnaire. A hundred percent response was not achieved due to some companies' policies, protocol, unavailability of personnel appropriate for interview, fear of being implicated by the survey and the inability of the interviewer to re-visit after previous attempts. However, the overall percent response was $68 \%$ which was above average. Table 1 shows percenttage response and their locations, while Figure 1 categorizes the type of business practiced by respondents. It is over 50 years since the first pharmaceutical industry started in Nigeria, an exporter of petroleum with a good potential of developing the petrochemical industry for supply of raw materials; yet no primary pharmaceutical manufacturers exist to date. From Figure 1, $44.1 \%$ of the respondents were involved in secondary manufacturing while $38.2 \%$ were engaged in secondary manufacturing and finished product importation. The temptation for manufacturers to get involved in product importation from Asia, especially, is very high as products imported end up being cheaper due to lack of overhead cost.

\section{Generation of pharmaceutical waste and wastewater}

The various forms of pharmaceutical waste generated by the industries are depicted in Figure 2. Only $17.7 \%$ admitted to have had formulations that were not reworkable, while $29.4 \%$ have had spillage of their pharmaceuticals. Some argued that they were manufacturing below installed capacity and so had no expired medicines except for quarantine samples. Some importers admitted to donating products that were close to expiry to physicians.

Most of the industries import raw materials while they source locally in emergency. Twenty one (61.8\%) admitted receiving low quality active pharmaceutical ingredients (APIs), while $20.6 \%$ admitted to have had expired APIs. Moreover, expired and low quality APIs are pharmaceutical wastes. Two of the respondents explained that they had expired APIs because the formulation of the products was discontinued.

Most of the respondents could not ascertain the quantity of waste generated. However, a few were specific and provided documentary evidence stating that quantity of waste is one of the requirements of regulatory authorities (U.S. Code, 2006; FEPA, 1991). Other respondents did not understand that it was necessary to know the quantity of waste generated as it would determine the method of disposal.

All manufacturing pharmaceutical industries generated wastewater, which resulted from the water used for process operations during manufacturing and in contact with intermediary, finished and/or by-products. Wastewater could come from the water used to clean equipment, pipes and floors, and would contain amongst other materials, chemicals and active pharmaceutical ingre- 
Table 1. Company locations and percent response.

\begin{tabular}{lccccc}
\hline Parameter & Lagos state & Ogun state & Niger state & Plateau state & Total \\
\hline Number of companies visited & 40 & 6 & 3 & 1 & 50 \\
Number of responses & 25 & 5 & 3 & 1 & 34 \\
Percent response $(\%)$ & 62.5 & 83.3 & 100 & 100 & 68 \\
\hline
\end{tabular}

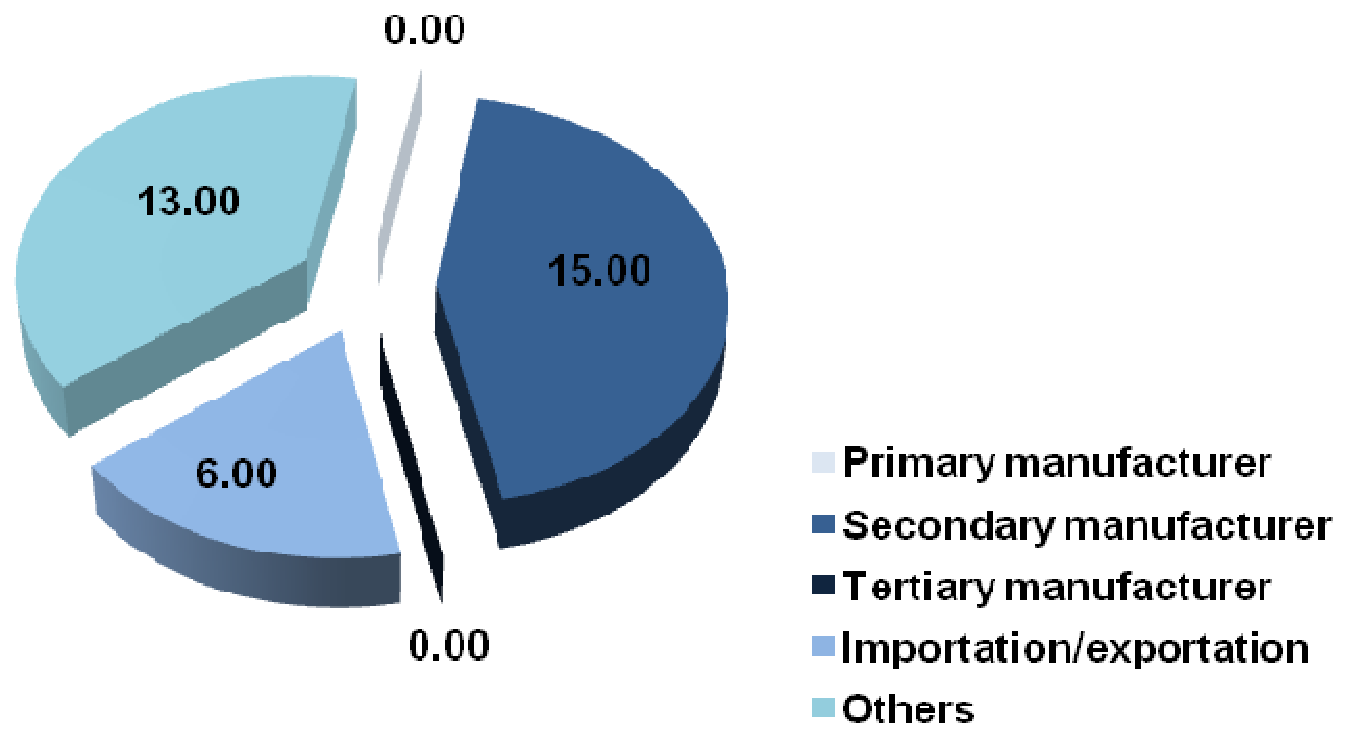

Figure 1. Classification of the respondents into types of pharmaceutical businesses.

dients (APIs).

The 1990 survey conducted by U.S EPA (environmental protection agency) consisting of 244 chemical facilities estimated the average daily wastewater generation by pharmaceutical industries to be 266 million gallons (1006919538.8 L) (EPA office of compliance, 1997). Documentation of the quantity of wastewater is lacking in the Nigerian Pharmaceutical Industry. Only a few have an estimate of the quantity of wastewater generated daily. Since wastewater is generated daily and contains chemicals and APIs, disposal of wastewater should be of interest to government regulatory authorities in order to protect public health.

\section{Disposal of waste}

\section{Pharmaceutical waste}

From the survey shown in Table 2, it was obvious that pharmaceutical waste and wastewater were improperly managed and disposed by the surveyed industries. Three respondents stated that Lagos State Environmental Protection Agency (LASEPA), in the presence of National
Agency for Food, Drug Administration and Control (NAFDAC) and a representative of the company, disposed their pharmaceutical waste. However, a visit to LASEPA by the authors revealed that as of the time of this study, only one company's waste had been disposed by the agency.

LASEPA revealed how pharmaceutical waste is disposed by the agency. First, an industry would write stating the drugs or raw materials to be disposed with the quantities. A staff of the agency would go to assess the waste, container, the chemical content and the quantity; and he would take samples for analysis. After confirmation, the industry is billed depending on the weight and level of toxicity. The samples are taken to the laboratory to determine a suitable solvent that will dissolve the waste. The identified solvent and pharmaceutical waste is mixed in a mixing tank, transferred into the diluting tank where $\mathrm{pH}$ is adjusted to neutral and diluted with water before the liquid is flushed into the environment. The packaging (bottles and drums) is crushed and buried at a dump site while paper packaging is burnt. Finally, a certificate is issued with a consignment note (consignment note is used to prepare the certificate). After disposal, a report is written and signed by a representative from the industry 


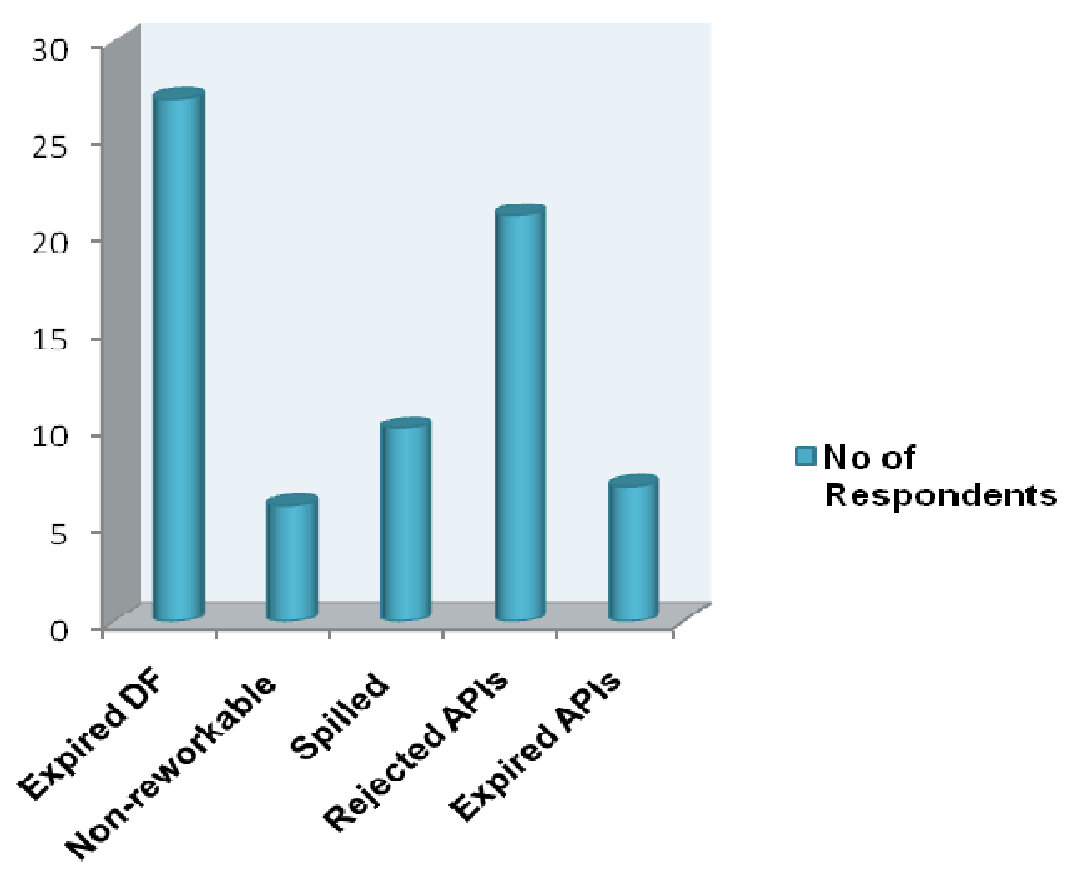

Figure 2. The various forms of pharmaceutical waste from the industries. (1) Expired dosage forms, (2) non-reworkable formulations, (3) spilled pharmaceuticals, (4) rejected active pharmaceutical ingredients, (5) expired active pharmaceutical ingredients.

and a senior officer from the agency. Dissolving pharmaceutical waste in a suitable solvent does not necessarily inactivate the pharmaceutical waste or their environmental and human impacts.

Some of the industries (29.4\%) flushed their pharmaceutical waste down the drain with lots of water. A section of these industries formulate antibiotics which are not to be discharged into drains or sewers. In fact, on no account should any quantity of pharmaceutical waste be disposed through the drain, slow moving or stagnant water bodies (Prüss et al. 1999). One industry permitted Lagos State Waste Management Authority (LAWMA) to dispose her pharmaceutical waste. However, LAWMA is equipped to manage non-hazardous waste while LASEPA is to manage hazardous waste.

Mixing of waste with sand and chemical disinfection is usually not adequate for pharmaceuticals, chemicals and some types of infectious waste. Burying of pharmaceutical waste is improper for environmental reasons, which include the leaching of the waste into ground water and surface water (Castensson, 2008; Kümmerer, 2009).

Returning materials below quality or of close expiration dates to suppliers may be ideal in developed countries, but in Nigeria where the local suppliers are not properly regulated and controlled, the same products could be repackaged and re-circulated. Re-exportation or reversed logistics of chemicals and pharmaceuticals out of Nigeria is illegal. These would lead to attempts to re-sell to unsuspecting customers, and in the event that they are unable to do so, the waste may be released into the environment and/or waters.

Open air burning practiced by the industries generates toxic emissions into the air. Pharmaceutical waste should be burnt in well-constructed incinerators at recommended temperatures with means of controlling emissions. Incineration with general or infectious waste can be undertaken as long as the pharmaceutical waste is not more than $1 \%$ of the total waste to limit toxic emissions into the air (Prüss et al., 1999). Three respondents dissolved their pharmaceutical waste in an undisclosed solvent followed by discharge through the effluent plant. This method is unconventional and would lead to the discharge of raw pharmaceutical waste into the environment and waters.

Indeed, incineration is the best method of disposing pharmaceutical waste. To ensure optimal combustion, it should be mixed with the packaging, while other combustible materials and infectious waste and combustion should be at $1000^{\circ} \mathrm{C}$ to burn off potentially toxic exhaust gases. For large pharmaceuticals, rotary kilns at temperatures greater than $1200^{\circ} \mathrm{C}$ are recommended.

\section{Wastewater}

Wastewater treated conventionally or untreated is 
Table 2. Methods of disposal of pharmaceutical waste and wastewater by the respondents.

\begin{tabular}{|c|c|c|c|}
\hline Pharmaceutical waste & $\begin{array}{l}\text { Number of } \\
\text { respondent }\end{array}$ & Wastewater & $\begin{array}{l}\text { Number of } \\
\text { respondent }\end{array}$ \\
\hline Flushed down the drain. & 10 & $\begin{array}{l}\text { Not treated and discharged into the } \\
\text { drain, canal or gutters. }\end{array}$ & 11 \\
\hline $\begin{array}{l}\text { Carried away by LAWMA for } \\
\text { destruction in the presence of } \\
\text { company's staff. }\end{array}$ & 1 & $\begin{array}{l}\text { Not treated and discharged into the } \\
\text { drain, but LASEPA often took } \\
\text { samples for analysis. }\end{array}$ & 2 \\
\hline $\begin{array}{l}\text { Burnt in the presence of NAFDAC or } \\
\text { LASEPA and company's staff. }\end{array}$ & 5 & $\begin{array}{l}\text { Treated in a tank and analyzed by } \\
\text { LASEPA before it is discharged into } \\
\text { the drain. }\end{array}$ & 8 \\
\hline Burnt on company's volition & 2 & Passed through the effluent plant. & 2 \\
\hline $\begin{array}{l}\text { Carted away by NAFDAC and a } \\
\text { certificate was issued. }\end{array}$ & 3 & $\begin{array}{l}\text { Collected into a reservoir and it } \\
\text { gradually sips into the soil. }\end{array}$ & 2 \\
\hline Buried within or near the premises. & 2 & $\begin{array}{l}\text { Collected into a tank and is later used } \\
\text { for gardening }\end{array}$ & 1 \\
\hline $\begin{array}{l}\text { Tablets are mixed with sand and water, } \\
\text { packed in a polythene bag and } \\
\text { discarded as general waste. }\end{array}$ & 1 & $\begin{array}{l}\text { Flows freely into farmlands and } \\
\text { streams around. }\end{array}$ & 1 \\
\hline $\begin{array}{l}\text { Burnt within the premises with general } \\
\text { waste }\end{array}$ & 1 & & \\
\hline $\begin{array}{l}\text { Dissolved and transferred into the } \\
\text { effluent plant. }\end{array}$ & 3 & & \\
\hline $\begin{array}{l}\text { Poured into a tank, disinfected, } \\
\text { allowed to stand for } 2 \text { days and } \\
\text { discharged into the drain. }\end{array}$ & 1 & & \\
\hline Rejected APIs returned to supplier & 21 & & \\
\hline $\begin{array}{l}\text { The supplier is informed of the rejected } \\
\text { APIs, but are disposed by LASEPA. }\end{array}$ & 1 & & \\
\hline
\end{tabular}

irrelevant as the pharmaceuticals are discharged into the waters. Studies have shown the prevalence of antibioticresistant pathogens in wastewater (Grabow and Prozesky, 1973; Guardabassi et al., 1998; Pruden et al., 2006; Reinthaler et al., 2003) leading to the challenges in antimicrobial therapy. Guardabassi and co-workers in their antibiotic resistance comparative study using wastewater from a hospital and a pharmaceutical plant found out that the wastewater from the pharmaceutical plant had increase in the prevalence of antibiotic resistance among Acinetobacter species (Guardabassi et al., 1998). A city like Lagos with more than 40 pharmaceutical industries may have increase in prevalence of antibiotic resistance as well as pharmaceuticals with concentrations that may be of great concern. The discharge of wastewater without proper treatment to remove pharmaceuticals may lead to contamination of drinking water.

$A$ visit to one of the environmental laboratories, registered with LASEPA, revealed the parameters analyzed in wastewater samples obtained from pharmaceutical industries to include chemical oxygen demand (COD), biological oxygen demand (BOD), trace heavy elements, microbiology, oil and grease, residual chlorine, total suspended solids (TSS), $\mathrm{pH}$, conductivity (reactions of ions), turbidity, chloride, nutrients (phosphates, sulphates, nitrates) and dissolved oxygen (DO). Apparently, neither the presence of 
Table 3. Performance of the industries on waste management.

\begin{tabular}{lcc}
\hline \multirow{2}{*}{ Criteria } & \multicolumn{2}{c}{ Company $\mathbf{n = 3 4}$} \\
\cline { 2 - 3 } & Number & (\%) \\
\hline Awareness of regulatory requirements & 25 & 73.5 \\
Availability of company's policy on waste & 13 & 38.2 \\
Trained staff on waste management & 14 & 41.2 \\
Availability of SOPs for waste management & 18 & 52.9 \\
Documentation of quantities of waste generated & 12 & 35.3 \\
Separation of waste & 24 & 70.6 \\
Use of recommended handling methods for Pharmaceutical waste & 00 & 0.0 \\
(incineration above $1000^{\circ} \mathrm{C}$, encapsulation, etc) & & \\
Use of non-recommended disposal method e.g. & 10 & 29.41 \\
(i) Open burning/burning below $1000^{\circ} \mathrm{C}$ & 16 & 47.06 \\
(ii) Discharge into public drains & 20 & 58.8 \\
Future plans on waste management & & \\
\hline
\end{tabular}

pharmaceuticals nor their quantities in the wastewater is determined. For those that have effluent plants, the plants are mainly designed to remove sediments and pathogens before the wastewater is released into the environment.

While developed countries may be exploring new technologies in treatment plants such as flocculation, ozonization, advanced oxidation, membrane filtration and photocatalysis to improve removal of pharmaceutical waste (Packer et al., 2003; Larsen et al., 2004; Zuccato et al., 2006), most developing countries such as Nigeria are yet to routinely pass wastewater through treatment plants before delivery into the lakes and rivers.

\section{Waste management practices}

Waste management requires the five pillars of management - planning, organizing, leading, coordinating and monitoring for efficacy and effectiveness. Management of waste involves waste segregation, waste collection, waste transportation, waste storage, waste disposal, waste minimization and reuse (Townend and Cheeseman, 2005). The performance of the industries on waste management practices is shown in Table 3.

Only $38.2 \%$ have policies on waste and three respondents made it clear that they have health, safety and environmental policies. Waste separation was undertaken as claimed by $70.6 \%$; however, on further probing, it was discovered that separation of waste was understood by some of the respondents as separation into solids and liquids. This could also imply that those who said they do not separate waste understood and sincerely admitted. More than $50 \%$ of the personnel, supposedly in charge of waste, were not trained to effectively manage waste. Those that were trained were either taught just the basics or had their training many years back and so were not aware of current trends in hazardous waste management. In most industries, it seemed the designated officers (quality assurance/control manager, production personnel, store man, compliance manager, gardener, etc) had waste management as an added portfolio and there was little or no supervision. It was only one industry that had a health, safety and environmental (HSE) officer. Three industries had waste management team comprising administration, quality assurance and production, while one of them had a more comprehensive team of production, quality assurance, finance, engineering and management or administration. The industry with a comprehensive team considers waste management as one of their priorities and so have periodical environmental auditing to assess their strength and weakness as they implement their waste policy.

It was also observed that those who claimed to have standard operating procedures (SOPs) do not have comprehensive SOPs on waste. Rather, they had SOPs on either cleaning or effluent water, microbial waste, waste disposal or handling of waste. The importers assumed that since they are not manufacturers, they do not need SOPs on waste, though they generate waste. Although, $73.5 \%$ of the respondents are aware of the regulatory requirements on waste, most of them do not adhere to them.

In reference to product recall, it was observed that $32.4 \%$ did not have written recall procedures and those that recalled $(35.3 \%)$ disposed the products improperly. Furthermore, as shown in Figure 3, most of the industries do not have disposal sites, while three respondents that had, undertook open burning on the sites and one had an incinerator. Waste, as well as treated waste, ought to be transported to a disposal site. The choice of disposal facilities is based on the type of treatment and the type of treatment can also affect the choice of disposal facilities (Nema and Gupta, 1999).

Although, improper waste management practices were observed in over $90 \%$ of the industries visited, $58.8 \%$ of them had future plans for waste which included building 


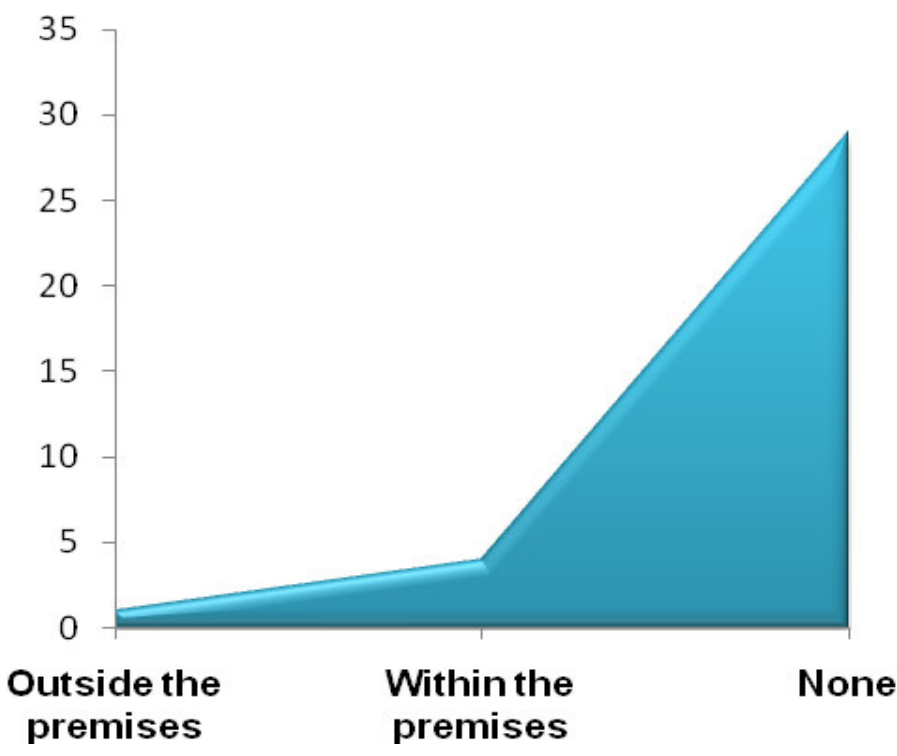

$\square$ No of respondents

Figure 3. Pharmaceutical Industries' possession of disposal sites.

of incinerators, construction or upgrading of waste treatment plants, enforcement of health safety and environmental policies, recycling of wastewater, minimization of waste and operating standard treatment of waste. Immediate outcomes of this study were the awareness created and the promise of prompt action by the focal persons and management.

\section{Challenges to managing pharmaceutical waste}

From interactions with the respondents, it could be deduced that the regulatory bodies were not adequately trained and educated to influence the management of hazardous waste and were not aware that pharmaceutical waste is an emerging contaminant of major concern. This could also be an indicator to the fact that the federal and state governments are yet to make waste management a priority. The health of a country is the wealth of the country; consequently, pharmaceutical waste is detrimental to the health and wealth of the people. While developed countries are researching to provide techniques on how to manage emerging contaminants such as pharmaceuticals, developing countries such as Nigeria are attempting to tackle solid waste (which is bedevilled by poor management) and still deliberating on healthcare waste with little attention from the government.

Although, regulatory authorities and ministries of environment have been set up, there are no indications that the regulatory bodies are fully equipped to function effectively. The pharmaceutical industries are not aware of any national policy on waste and some available guidelines are not specific on how to manage and dispose pharmaceutical waste. In fact, it appeared that
Nigeria does not have a healthcare waste management policy and plan. Awareness is apparently lacking, although, one of the states (Lagos) has been having annual summits on waste management. However, lacks of training, monitoring and evaluation skills, storage and disposal facilities are major challenges to implementation.

As the research on the effects of pharmaceutical waste on humans, quantification of the individual drugs, the synergistic effect or additives effects of the drugs, the right analytical techniques for assessment of pharmaceutical waste and the technology and cost of improving the treatment plant continues, one cannot but agree with Daughton who opined that the reality is to go back to the basics and prevent the entry of pharmaceuticals into the aquatic environment than try to determine their harmful effects at the expense of animals, time and finance. However, if the risks must be assessed, they should be done with minimal resources (Daughton, 2002).

\section{Conclusion and recommendations}

There is need to sustain the environment by standard and environmental friendly methods of managing waste so that we do not employ makeshift solutions for today's problem, which will create greater problems for the next generations. Management of waste should be planned, documented, implemented and sustained.

Most generators of hazardous waste are not aware of the health and environmental implications of improper disposal and so public awareness and training are imperative. Such training should be done for the staff of the regulatory authorities, the key players in the public and private sectors, industrial and health workers and 
even the public. However, the level of training will differ with each group.

As much as the regulatory authorities have been involved with treatment and disposal, management of waste should also include prevention and minimization. They should arise to their full responsibility of waste management. The regulatory bodies should not be in competition/fight over who is in charge of waste as reported by some respondents. Incineration rather than open burning should be employed and so incinerators with emissions control should be provided.

Wastewater treatment plants with modern technologies such as ozonization and membrane filtration can be set up in the industrial estates to help those that cannot afford to own one. Services can be paid for by the industries to help with the maintenance of the plants. The treatment facilities should also be able to recycle water so that it can be fit for other purposes such as gardening.

Industries should be supported to set up waste management teams, draft and implement waste management plans. There should be incentives, such as financial support, provision of industrial disposal units and free training of staff to encourage waste management. This will also diffuse the notion some respondents have about the regulatory authorities having levying it as its priority. Incentives are avenues for regulatory bodies to give back to the industries and also a means of motivating people to comply. The United States environmental protection agency's (U.S.EPA) program 'WasteWise', which is a forum where the industries can share their activities and achievements on how they are able to minimize waste and cut costs, may be adopted.

\section{REFERENCES}

Bassey BE, Benka-Coker MO, Aluyi HSA (2006). Characterization and management of solid medical wastes in the Federal Capital Territory, Abuja Nigeria. Afri. Health Sci. 6: 58-63.

Berry MA, Rondinelli DA (2000). Environmental Management in the Pharmaceutical Industry: Integrating Corporate Responsibility and Business Strategy. Environ. Qual. Manage. 9: 21-35.

Bound JP, Voulvoulis N (2006). Predicted and measured concentrations for selected pharmaceuticals in UK rivers: Implications for risk assessment. Water Res. 40 (15): 2885-2892.

Buser H, Poiger T, Müller MD (1999). Occurrence and Environmental Behavior of the Chiral Pharmaceutical Drug Ibuprofen in Surface Waters and in Wastewater. Environ. Sci. Technol. 33 (15): 2529-2535.

Castensson S (2008). Pharmaceutical Waste. In: Kümmerer K (ed.), Pharmaceuticals in the Environment: Sources, Fate, Effects and Risks, 489-499, $3^{\text {rd }}$ revised and enlarged edition, Berlin, Germany, Springer Berlin Heidelberg.

Cleuvers M (2003). Aquatic ecotoxicity of pharmaceuticals including the assessment of combination effects. Toxicol. Lett. 142 (3): 185-194.

Coker A, Sangodoyin A, Sridhar M, Booth C, Olomolaiye P, Hammond $F$ (2009). Medical waste management in Ibadan, Nigeria: Obstacles and prospects. Waste Manage. 29 (2): 804-811.

Daughton CG (2002). Environmental stewardship and drugs as pollutants. The Lancet 360: 1035-1036.

De Lange HJ, Noordoven W, Murk AJ, Lürling M, Peeters ETHM (2006). Behavioural responses of Gammarus pulex (Crustacea, Amphipoda) to low concentrations of pharmaceuticals. Aquat. Toxicol. 78 (3): 209216.
EPA office of compliance (1997). Profile of the pharmaceutical industry. EPA/310-R-97-005 SIC Code: 2833, 2834, 48-50.

Erickson BE (2002). Analyzing the Ignored Environmental Contaminants. Environ. Sci. Technol. 36 (7): 140A-145A.

Fenske M, Maack G, Schafers C, Segner H (2005). An environmentally relevant concentration of estrogen induces arrest of male gonad development in zebrafish, Danio rerio. Environ. Toxicol. Chem. 24 (5): 1088-1098.

Fent K, Weston AA, Caminada D (2006). Ecotoxicology of human pharmaceuticals. Aquat. Toxicol. 76 (2): 122-159.

FEPA (1991). National Interim Guidelines and Standards for Industrial Effluents, Gaseous Emissions and Hazardous Wastes Management in Nigeria.

Fick J, Soderstrom H, Lindberg RH, Phan C, Tysklind M, Larsson DGJ (2009). Contamination of surface, ground, and drinking water from pharmaceutical production. Environ. Toxicol. Chem. 28 (12): 25222527.

Grabow WOK, Prozesky OW (1973). Drug Resistance of Coliform Bacteria in Hospital and City Sewage. Antimicrob. Agents Chemother. 3 (2): 175-180.

Guardabassi L, Petersen A, Olsen JE, Dalsgaard A (1998). Antibiotic Resistance in Acinetobacter spp. Isolated from Sewers Receiving Waste Effluent from a Hospital and a Pharmaceutical Plant. Appl. Environ. Microbiol. 64 (9): 3499-3502.

Heberer T (2002). Occurrence, fate, and removal of pharmaceutical residues in the aquatic environment: a review of recent res. data. Toxicol. Lett. 131 (1-2): 5-17.

Hektoen H, Berge JA, Hormazabal V, Yndestad M (1995). Persistence of antibacterial agents in marine sediments. Aquaculture, 133 (3-4): 175-184.

Henschel K-P, Wenzel A, Diedrich M, Fliedner A (1997). Environmental Hazard Assessment of Pharmaceuticals. Regulatory Toxicol. Pharmacol. 25 (3): 220-225.

Huggett DB, Brooks BW, Peterson B, Foran CM, Schlenk D (2002). Toxicity of Select Beta Adrenergic Receptor-Blocking Pharmaceuticals (B-Blockers) on Aquatic Organisms. Arch. Environ. Contam. Toxicol. 43 (2): 229-235.

Jones OAH, Voulvoulis N, Lester JN (2002). Aquatic environmental assessment of the top 25 English prescription pharmaceuticals. Water Res. 36 (20): 5013-5022.

Keil F, Bechmann G, Kummerer K, Schramm E (2008). Systemic Risk Governance for Pharmaceutical Residues in Drinking Water. GAIA Ecol. Perspectives for Sci. Society 17(7): 355-361.

Kümmerer K (2008). Pharmaceuticals in the Environment - A Brief Summary. Pharmaceuticals in the Environment: Sources, Fate, Effects and Risks, 3-21, $3^{\text {rd }}$ revised and enlarged edition, Berlin, Germany, Springer Berlin Heidelberg.

Kümmerer K (2009). The presence of pharmaceuticals in the environment due to human use - present knowledge and future challenges. J. Environ. Manage. 90 (8): 2354-2366.

Lange R, Hutchinson TH, Croudace CP, Siegmund F (2001). Effects of the synthetic estrogen 17a-ethinylestradiol on the life-cycle of the fathead minnow (Pimephales promelas). Environ. Tox. Chem. 20 (6): 1216-1227.

Larsen TA, Lienert J, Joss A, Siegrist H (2004). How to avoid pharmaceuticals in the aquatic environment. J. Biotechnol. 113 (1-3): 295-304.

Larsson DGJ, de Pedro C, Paxeus N (2007). Effluent from drug manufactures contains extremely high levels of pharmaceuticals. J. Hazard. Mater. 148 (3): 751-755.

Latch DE, Stender BL, Packer JL, Arnold WA, McNeill K (2003). Photochemical Fate of Pharmaceuticals in the Environment Cimetidine and Ranitidine. Environ. Sci. Technol. 37 (15): 3342-3350.

Li D, Yang M, Hu J, Zhang Y, Chang H, Jin F (2008). Determination of penicillin $G$ and its degradation products in a penicillin production wastewater treatment plant and the receiving river. Water Res. 42 (12): 307-317.

Lin AY, Tsai Y (2009). Occurrence of pharmaceuticals in Taiwan's surface waters: Impact of waste streams from hospitals and pharmaceutical production facilities. Sci. Total Environ. 407 (12): 3793-3802.

Longe EO, Williams A (2006). A preliminary study of medical waste 
management in Lagos metropolis, Nigeria. Iranian J. Environ. Health Sci. Engineering 3 (2): 133-139.

Nema, AK, Gupta SK (1999). Optimization of regional hazardous waste management systems: an improved formulation. Waste Manage. 19 (7-8): 441-451.

Ngwuluka N, Ochekpe N, Odumosu P, John S (2009). Waste management in healthcare establishments within Jos Metropolis, Nigeria. Afr. J. Environ. Sci. Technol. 3 (12): 459-465.

Oaks JL, Gilbert M, Virani MZ, Watson RT, Meteyer CU, Rideout BA, Shivaprasad HL, Ahmed S, Iqbal Chaudhry, MJ, Arshad M, Mahmood S, Ali A, Ahmed Khan A (2004). Diclofenac residues as the cause of vulture population decline in Pakistan. Nature, 427: 630-633.

Packer JL, Werner JJ, Latch DE, McNeill K, Arnold WA (2003). Photochemical fate of pharmaceuticals in the environment: Naproxen, diclofenac, clofibric acid, and ibuprofen. Aquat. Sci. - Res. Across Boundaries 65 (4): 342-351.

Pomati F, Netting AG, Calamari D, Neilan BA (2004). Effects of erythromycin, tetracycline and ibuprofen on the growth of Synechocystis sp. and Lemna minor. Aquat. Toxicol. 67 (4): 387-396.

Pruden A, Pei R, Storteboom H, Carlson KH (2006). Antibiotic Resistance Genes as Emerging Contaminants: Studies in Northern Colorado. Environ. Sci. Technol. 40 (23): 7445-7450.

Prüss A, Giroult E, Rushbrook P (1999). Safe Management of Wastes from Health-Care Activities, World Health Organization, Geneva.

Reinthaler FF, Posch J, Feierl G, Wüst G, Haas D, Ruckenbauer G, Mascher F, Marth E (2003). Antibiotic resistance of $E$. coli in sewage and sludge. Water Res. 37 (8): 1685-1690.

Richards SM, Wilson CJ, Johnson DJ, Castle DM, Lam M, Mabury SA, Sibley PK, Solomon KR (2004). Effects of Pharmaceutical Mixtures in Aquatic Microcosms. Environ. Toxicol. Chem. 23 (4): 1035-1042.

Roberts PH, Thomas KV (2006). The occurrence of selected pharmaceuticals in wastewater effluent and surface waters of the lower Tyne catchment. Sci. Total Environ. 356 (1-3): 143-153.

Sacher F, Lange FT, Brauch H, Blankenhorn I (2001). Pharmaceuticals in groundwaters: Analytical methods and results of a monitoring program in Baden-Württemberg, Germany. J. Chromatography A 938 (1-2): 199-210.
Selvik A, Kupka Hansen P, Ervik A, Bent Samuelsen O (2002). The stability and persistence of diflubenzuron in marine sediments studied under laboratory conditions and the dispersion to the sediment under a fish farm following medication. Sci. Total Environ. 285 (1-3): $237-$ 245.

Sherer JT (2006). Pharmaceuticals in the environment. Am J Health Syst. Pharm. 63 (2): 174-178.

Stumpf M, Ternes TA, Wilken R, Rodrigues SV, Baumann W (1999). Polar drug residues in sewage and natural waters in the state of Rio de Janeiro, Brazil. Sci. Total Environ., 225 (1-2): 135-141.

Ternes TA (1998). Occurrence of drugs in German sewage treatment plants and rivers. Water Res. 32 (11): 3245-3260.

Townend WK, Cheeseman CR (2005). Guidelines for the evaluation and assessment of the sustainable use of resources and of wastes management at healthcare facilities. Waste Manage. Res. 23 (5): 398-408.

US Code (2006). US code Title 42 - The public health and welfare. 82: 6922.

Zuccato E, Calamari D, Natangelo M, Fanelli R (2000). Presence of therapeutic drugs in the environment. The Lancet 355 (9217): 17891790 .

Zuccato E, Castiglioni S, Fanelli R (2005). Identification of the pharmaceuticals for human use contaminating the Italian aquatic environment. J. Hazard. Mater., 122 (3): 205-209.

Zuccato E, Castiglioni S, Fanelli R, Reitano G, Bagnati R, Chiabrando C, Pomati F, Rossetti C, Calamari D (2006). Pharmaceuticals in the Environment in Italy: Causes, Occurrence, Effects and Control. Environ. Sci. Pollution Res., 13 (1): 15-21. 